\title{
Estrous Characteristics of Lactating Saanen Ettawah Crossbred (SAPERA) Does on Different Parturition
}

\author{
Seraphina Kumala ${ }^{1}$, Yustina Yuni Suranindyah ${ }^{2}$ and Diah Tri Widayati ${ }^{1, *}$ \\ ${ }^{I}$ Department of Animal Breeding and Reproduction, Faculty of Animal Science, Universitas Gadjah Mada, Jl. Fauna \\ No.3 Bulaksumur, Yogyakarta, 55281, Indonesia \\ ${ }^{2}$ Department of Animal Production, Faculty of Animal Science, Universitas Gadjah Mada, Jl. Fauna No.3 Bulaksumur, \\ Yogyakarta, 55281, Indonesia \\ ${ }^{*}$ Corresponding author. Email: widayati@ugm.ac.id
}

\begin{abstract}
Goat's lactation ability is affected by its reproductive ability to produce kids. Doe's parturition is one of the most important considerations for goat's milk production sustainability. This research aimed to determine the estrous characteristics in lactating Saanen Ettawah Crossbred (SAPERA) on different parturition. Forty-eight SAPERA does with body condition score \pm 3 on natural estrous cycle were used in this study. The does were divided into 3 groups based on parturition amount (parturition 1; parturition 2; parturition >3). This research was administered under similar condition and management in a traditional milking goat farm at Turi District, Yogyakarta. The collected data were scoring of vaginal characteristics (reddening vulva, mucus discharge and swollen vulva); mucus $\mathrm{pH}$ value; and vaginal temperature. The $\mathrm{pH}$ value and vaginal temperature were also used to determine the estrous phase of does. The data were analysed using a completely randomized design (CRD) continued with Post-hoc (LSD). The result of vaginal characteristics and temperature were significantly different $(\mathrm{P}<0.05)$. It tended to decrease following the increase of parturition. The vaginal temperature in the parturition 1,2 and 3 groups were $38.49 \pm 0.50,38.24 \pm 0.42$, and $38.69 \pm 0.31$, respectively. The $\mathrm{pH}$ mucus did not differ significantly between parturition groups. In conclusion, the estrous characteristics in lactating SAPERA does were affected by parturition. However, it still needs further study.
\end{abstract}

Keywords: Estrous characteristics, Lactation, Vaginal temperature, Parturition, SAPERA does.

\section{INTRODUCTION}

Goat is one of the livestock that can produce milk and meat. Goat's milk is prospective for consumption in Indonesia due to its high nutritional value can increase the consumers' health. Smallholder farmers with traditional management were dominated the majority of goat milk production in Indonesia. Good reproductive management is needed to deliver efficient goat milk production. The goat's lactation ability is influenced by its ability to produce kids. Doe's parturition is one of the most important considerations for goat's milk production sustainability. Nutritional deficiencies and imbalances in energy, protein, minerals and vitamins are the primary reproductive problems [1]. In the previous study, parturition and the onset of lactation impose great metabolic stress on ruminants (cow), leading to nutrient deficiency, decreasing the immune system, and cause hormonal changes [2]. The changes in reproductive hormones that regulated by the hypothalamic-pituitary- gonadal axis (HPG) will influence the estrous characteristics [3].

Does would receive mating only on the estrous phase. Therefore, smallholder farmers need to observe the best time for mating. Usually, observation is based on visual characteristics such as vaginal characteristics (reddening, mucus discharge, swollen). The intensity of vaginal characteristics, vaginal temperature, and mucus $\mathrm{pH}$ value was affected by estrogen hormone level. Estrogen plays an essential role in the onset estrous and the appearance of estrous signs [4]. The effect of increased parturition on reproductive ability was still questionable, even though previous negative energy and protein balance occurs. This study was considered valuable because of the comparation on estrous characteristics between different parturition in tropical SAPERA does with natural estrous cycle. It was speculated that the increase of parturition would decrease the estrous characteristics. Therefore, this research aimed to determine the estrous characteristics in lactating Saanen Ettawah Crossbred (SAPERA) on different parturition. 


\section{MATERIALS AND METHOD}

\subsection{Experimental Animals}

Forty-eight lactating SAPERA does were used in this study with a body condition score (BCS) \pm 3 . The does were kept under similar condition and management at Turi District, Yogyakarta. The does were divided into 3 groups based on parturition (Group 1: parturition 1; Group 2: parturition 2; Group 3: parturition >3). The feed provided consists of legumes and concentrate. Water was provided ad-libitum. The nutrients content of concentrate based on proximate analysis were dry matter $2.54 \%$; ash $0.4 \%$; crude protein $0.45 \%$; ether extract $0.1 \%$; crude fiber $0.74 \%$; nitrogen free extract $1.4 \%$; and estimated total digestible nutrient $1.83 \%$.

\subsection{Observation of Estrous Characteristics}

Observation of estrous characteristics consisted of vaginal characteristics (swollen vulva, mucus discharge, and reddening of vulva), mucus $\mathrm{pH}$ value, and vaginal temperature. Data of vaginal characteristics were obtained using scoring (1-3). The criteria of vaginal characteristics scoring presented in Table 1 [4], [5]. Data of mucus $\mathrm{pH}$ value were obtained by using $\mathrm{pH}$-meter (Merck KGaA, Germany) [3], [6]. Data of vaginal temperature were obtained by using digital thermometer (Omron, Indonesia) that had been cleaned with alcohol $70 \%$ [5]. Data of vaginal temperature and mucus $\mathrm{pH}$ value were used to identify of estrous phase of does.

Table 1. The criteria of vaginal characteristics scoring

\begin{tabular}{|l|l|l|l|}
\hline Criterion & 1 & 2 & 3 \\
\hline $\begin{array}{l}\text { Swollen } \\
\text { vulva }\end{array}$ & $\begin{array}{l}\text { No } \\
\text { swollen }\end{array}$ & $\begin{array}{l}\text { Wrinkled } \\
\text { texture } \\
\text { starting to } \\
\text { become } \\
\text { unclear }\end{array}$ & $\begin{array}{l}\text { Enlarge } \\
\text { vulva, } \\
\text { wrinkled } \\
\text { become } \\
\text { unclear }\end{array}$ \\
\hline $\begin{array}{l}\text { Mucus } \\
\text { Discharge }\end{array}$ & No mucus & Little mucus & $\begin{array}{l}\text { Thick } \\
\text { mucus } \\
\text { until } \\
\text { hanging }\end{array}$ \\
\hline $\begin{array}{l}\text { Reddening } \\
\text { of vulva }\end{array}$ & Pale pink & Pink & Red \\
\hline
\end{tabular}

\subsection{Data Analyses Method}

The data of vaginal characteristics such as reddening vulva, mucus discharge, swollen vulva; mucus $\mathrm{pH}$ value, and vaginal temperature were analysed using a completely randomized design (CRD) and continued with Post-hoc (LSD) Test from IBM SPSS Statistics 25. The data were presented in mean \pm SD.

\section{RESULT AND DISCUSSION}

Reproduction health may be considered to guarantee the continuity of milk production in SAPERA does. The results of this study were showed in Table 2 . The result showed significant differences $(\mathrm{P}<0.05)$ in vaginal characteristics and temperature between parturition groups. The result of vaginal temperature during estrous phase was similar compared to the previous study which resulted $38.49 \pm 0.34^{\circ} \mathrm{C}$ in SAPERA does [4] and $39.60 \pm 0.26^{\circ} \mathrm{C}$ in Ettawah croessed breed [5].

Table 2. Estrous characteristics of SAPERA does on different parturition $($ mean \pm SD)

\begin{tabular}{|l|l|l|l|}
\hline $\begin{array}{l}\text { Estrous } \\
\text { characteristic }\end{array}$ & $\begin{array}{l}\text { Parturition 1 } \\
(\mathrm{n}=17)\end{array}$ & $\begin{array}{l}\text { Parturition 2 } \\
(\mathrm{n}=17)\end{array}$ & $\begin{array}{l}\text { Parturition 3 } \\
(\mathrm{n}=14)\end{array}$ \\
\hline $\begin{array}{l}\text { Swollen } \\
\text { vulva }\end{array}$ & $2.18 \pm 0.53^{\mathrm{a}}$ & $1.41 \pm 0.51^{\mathrm{b}}$ & $1.28 \pm 0.47^{\mathrm{c}}$ \\
\hline $\begin{array}{l}\text { Mucus } \\
\text { discharge }\end{array}$ & $2.71 \pm 0.47^{\mathrm{a}}$ & $2.12 \pm 0.69^{\mathrm{b}}$ & $2.00 \pm 0.00^{\mathrm{c}}$ \\
\hline $\begin{array}{l}\text { Reddening } \\
\text { of vulva }\end{array}$ & $2.23 \pm 0.75^{\mathrm{a}}$ & $2.06 \pm 0.43^{\mathrm{b}}$ & $1.64 \pm 0.49^{\mathrm{c}}$ \\
\hline $\begin{array}{l}\text { Mucus pH } \\
\text { value }\end{array}$ & $9.88 \pm 0.51$ & $9.82 \pm 0.43$ & $9.82 \pm 0.37$ \\
\hline $\begin{array}{l}\text { Vaginal } \\
\text { temperature }\end{array}$ & $38.49 \pm 0.50^{\mathrm{b}}$ & $38.24 \pm 0.42^{\mathrm{c}}$ & $38.69 \pm 0.31^{\mathrm{a}}$ \\
\hline $\begin{array}{l}\mathrm{a}, \mathrm{b}, \mathrm{c} \text { total means within column differs significantly } \\
(\mathrm{P}<0.05)\end{array}$
\end{tabular}

Vaginal characteristics such as reddening vulva, mucus discharge and swollen vulva were stated in scores $1-3$, and the result was similar to the previous study on estrous phase [7]. In addition, the estrous phase can be observed by measuring the $\mathrm{pH}$ of mucus. The $\mathrm{pH}$ mucus did not differ significantly between parturition groups. The $\mathrm{pH}$ mucus in this study was lower than previous study on Sapera does $(10.26 \pm 1.36)$ [8] but was higher than previous study on Ettawah crossed breed does $(8.00 \pm 0.61)$ [4]. Vaginal characteristics based on the observations in reddening vulva, mucus discharge, and swollen vulva were decreased $(\mathrm{P}<0.05)$ following the increase of parturition.

Parturition is the delivery process of the fully-grown foetus during the pregnancy period [9]. Parturition was important because the subsequent gestation depends on the return of the normal estrous and the uterine environment [10]. After parturition, there were significant problems such as the expulsion of placental remnants, involution of the uterus, and resumption of ovarian activity. It would affect the subsequent reproductive health and fertility [11]. The amount of parturition in does were suspected of impacting subsequent reproductive performance due to the metabolic stress. The requirement of nutrients and energy in the dairy ruminant tent to increase after parturition [12]. Negative energy balance was defined as an 
imbalance between dry matter intake and requirement. Therefore, female ruminants were lost more than $60 \%$ of body fat in the first weeks of calving [13]. The low level of nutrition would delayed the estrous even silent heat [10]. Meanwhile, the delay and missed of the estrous phase would prolong days open.

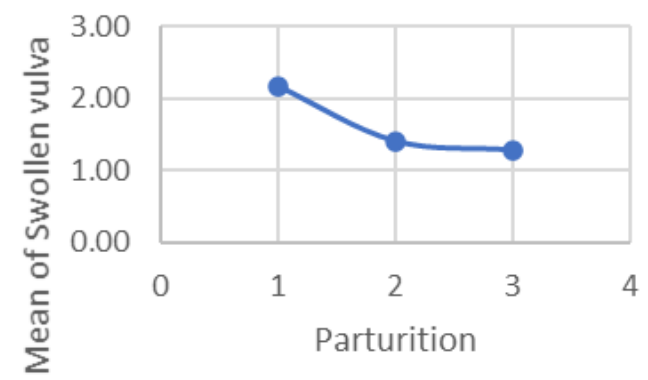

Figure 1 Swollen vulva on different parturition

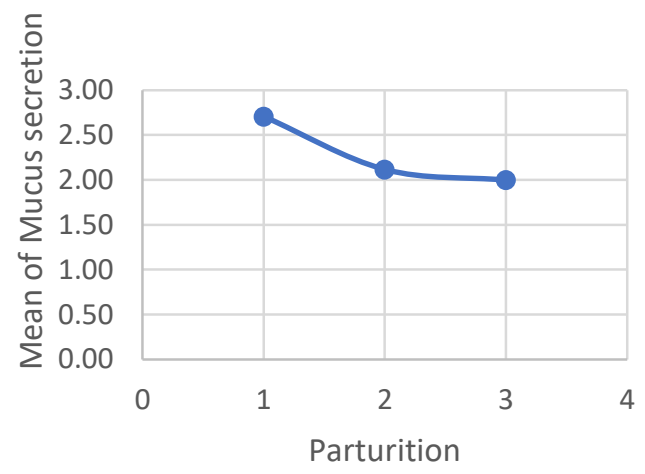

Figure 2 Mucus secretion on different parturition

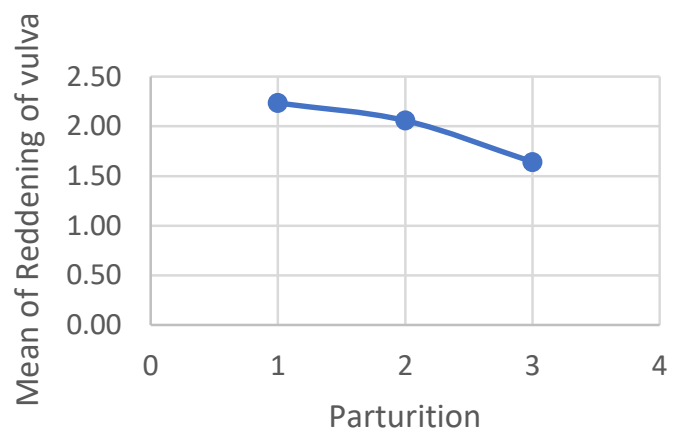

Figure 3 Reddening of vulva on different parturition

From the present study, it was showed that vaginal characteristics such as mucus discharge (Figure 1), reddening of vulva (Figure 2), and swollen vulva (Figure 3 ) tend to decrease from parturition 1 until 3. Estrous characteristic was affected by the increase of estrogen hormone level in blood [4]-[6], [8]. During the estrous phase, the does showed moderate swelling of the vulva and mucus discharge. However, the does with the weak estrous sign only showed tail wagging and standing for mating [10]. The changes in vaginal $\mathrm{pH}$ tends to increase during estrous and decrease after ovulation. It was happened due to accumulation of ions (hydrogen, sodium, chloride), glycogen and protein in the vagina [8].

Based on the previous study [14], the rise of estrogen concentrations was cognate with follicular development under the leverage of HPG (hypothalamus-pituitary gonadotropins) axis activity. It was confirmed by Goff and Horst [2] that the hormonal changes were associated with parturitions. Mohebbi et al [13] was reported that the first parturition in cow mobilized fewer fatty resources than parturition 2 and 3. The negative energy balance in cows affected the changes in the expression profile of genes involved in lipid and adipose tissue metabolism and reproductive function [15]. The glucose and lipid metabolism changes would induce the distinction of metabolic and endocrine states [12]. Therefore, the present study showed that the reproductive performance based on estrous characteristics tend to decrease following the increase of parturition. The result was showed the normal range of the estrous characteristics in parturition group 1, 2, and 3 respectively. This study was also expected as consideration in the culling management regarding lactating SAPERA does. However, it needs further study to understand the changes of blood metabolite following the increase of parturition amount.

\section{CONCLUSION}

This study indicated that estrous characteristics were affected by parturition. Vaginal characteristics such as reddening vulva, swollen vulva, mucus discharge, and mucus $\mathrm{pH}$ value tend to decrease following the increase of parturition in lactating SAPERA does. However, further study is still needed to confirm the changes in doe's blood metabolite.

\section{AUTHORS' CONTRIBUTION}

SK contemplated and executed the field work for data collection. SK, YYS and DTW drafted the manuscript paper. SK did the literature search and statistical analysis. All authors executed the interpretation of analyzed data and revised the manuscript. The research design was supervised by DTW and YYS. All of the involved authors had reviewed and approved the final version of manuscript.

\section{ACKNOWLEDGMENTS}

Author would like to thank the milking goat farm in Turi District, Yogyakarta for providing facilities and support to this research. Author also would like to thank Universitas Gadjah Mada for sponsoring this study 
through grant of Rekognisi Tugas Akhir (3134/UN1.P.III/DIT-LIT/PT/2021).

\section{REFERENCES}

[1] D.T. Widayati, D. Ikasari, S. Bintara, I. Natawihardja, K. Kustono, and Y.Y. Suranindyah, Evaluation of etawah grade doe fertility based on milk urea nitrogen levels, Int. J. Dairy Sci. vol. 12 issue 4, 2017, pp. 295-300. DOI: https://dx.doi.org/ $\underline{10.3923 / i j d s .2017 .295 .300}$

[2] J.P. Goff and R.L. Horst. Physiological changes at parturition and their relationship to metabolic disorders, J. Dairy Sci. vol. 80 issue 7, 1997, pp: 1260-1268. DOI: https://doi.org/10.3168/jds.s0022$\underline{0302(97) 76055-7}$

[3] P.I. Sitaresmi, B.P. Widyobroto, S. Bintara, and D.T. Widayati. Effects of body condition score and estrus phase on blood metabolites and steroid hormones in Saanen goats in the tropics, Vet. World. vol. 13 issue 5, 2020, pp: 833-839. DOI: https://doi.org/10.14202/vetworld.2020.833-839

[4] D.T. Widayati, M. Suryaputri, and Y.Y. Suranindyah. The effect of body condition score on estrous postpartum of ettawa crossed breed does in Girikerto farmer group, Turi, Sleman, Conf. 2nd Animal Production International Seminar (The 2 nd APIS), 2013, pp: 111-116. https://scholar. google.com/scholar?oi=bibs\&cluster $=7487164723$ $133208850 \& b \operatorname{bnI}=1 \& h l=e n$

[5] M. Ridlo, R. Ummami., N.W.Y. Dalimunthe., D. Ramandani., N.I. Prihani., M. Andityas., dan T.S.M. Widi. Profil vulva dan suhu tubuh kambing peranakan Etawa pada sinkronisasi estrus menggunakan medroxy progesterone acetate dan suplementasi zinc (Zn), J. Nas. Teknol. Terap. vol. 2 issue 2, 2018, pp: 198-211. DOI: https://doi.org/ 10.22146/jntt.42755

[6] I. Nurfitriani, R. Setiawan., and Soeparna. Karakteristik vulva dan sitologi sel mucus dari vagina fase estrus pada domba lokal. Students EJournal Unpad. vol. 4 issue 3, 2015, pp: 1-10. http://jurnal.unpad.ac.id/ejournal/article/view/6915/ $\underline{3230}$

[7] B.A. Atmoko, S. Bintara, D. Maharani, A. Ibrahim, and I.G.S. Budisatria, Estrous response of Etawah Crossbred does on estrous synchronization using the prostaglandin $\mathrm{f} 2 \alpha$ based protocol, IOP Conf. Ser. Earth Environ. Sci. vol. 465, 2020, pp: 1-5. DOI: https://doi.org/10.1088/1755-1315/465/1/012044

[8] D.T. Widayati, P. I. Sitaresmi, S. Bintara, and B. P. Widyobroto. Estrus detection through vaginal $\mathrm{pH}$ in Saanen Etawah Crossbreed goats, Pakistan J. Biol.
Sci, vol. 21 issue 8, 2018, pp: 383-386. DOI: https://doi.org/10.3923/pjbs.2018.383.386

[9] A. Hossein, A. Safdar, and N. M. Kor, Parturition mechanisms in ruminants: A complete overview. European Journal of Experimental Biology, vol. 4 issue 3, 2014, pp: 211-218. https://www.imedpub .com/articles/parturition-mechanisms-in-ruminantsa-complete-overview.php?aid $=15619$

[10] H.J. Bearden, J. W. Fuquay, and S.T. Willard, Applied Animal Reproduction, Prentice Hall-Upper Saddle River. New Jersey, 2004

[11] O. Peltoniemi, S. Björkman, and C. Oliviero, Parturition effects on reproductive health in the gilt and sow, Reproduction in Domestic Animals, vol. 51 issue 2, 2016, pp: 36-47. DOI: https://doi.org/ $\underline{10.1111 / \text { rda. } 12798}$

[12] J.J. Gross, E. C. Kessler, C. Albrecht, and R. M. Bruckmaier, Response of the cholesterol metabolism to a negative energy balance in dairy cows depends on the lactational stage. PLoS One, vol. 10, 2015. DOI: https://doi.org/10.1371/journal. pone.0121956

[13] M.R. Mohebbi, S. Lotfollahzadeh., and M.M. Sadegh. Evaluation of negative energy balance in dairy cows in Qom province, and its relationship with periparturient diseases. J. Dairy Vet. Sci, vol. 10 issue 2, 2019. DOI: https://dx.doi.org/10.19080/ JDVS.2019.10.555783

[14] X.S. Pang, Z.Y. Wang, T.G. Zhu, D.Z. Yin, Y.L. Zhang., L. Meng, and F. Wang. Concentrations of progesterone and estradiol in peripheral plasma during the estrous cycle and after ovariectomy in Huanghuai goats of high or poor prolificiacy, AsianAustralian J. Anim. Sci, vol. 23 issue 2, 2010, pp: 188-196. DOI: https://doi.org/10.5713/ajas.2010. $\underline{90211}$

[15] N. Mellouk, C. Rame, D. Naquin, Y. Jaszczyszyn, J.L. Touze, E. Briant, D. Guillaume, T. Ntallaris, P. Humblot, and J. Dupont, Impact of the severity of negative energy balance on gene expression in the subcutaneous adipose tissue of periparturient primiparous Holstein dairy cows: Identification of potential novel metabolic signals for the reproductive system, PLoS One, vol. 14 issue 9, 2019. DOI: https://doi.org/10.1371/journal.pone. 0222954 